\title{
THE EFFECT OF PARANET SHADE ON THE GROWTH AND MORPHOLOGICAL CHARACTERISTICS IN SIX SPECIES OF MANGROVE SEEDLING
}

\author{
MOHAMMAD BASYUNI*, TRY MIHARZA, EVAN KHAROGI SINULINGGA, \\ EPIFANI NATALIA GULTOM and YUNASFI DJAYUS \\ Department of Forestry, Faculty of Forestry, Universitas Sumatera Utara, \\ Jl. Tri Dharma Ujung No. 1 Medan, North Sumatra 20155, Indonesia \\ *E-mail:m.basyuni@usu.ac.id
}

Accepted 22 April 2020, Published online 6 July 2020

\begin{abstract}
In mangrove rehabilitation, nursery operation was required to enhance survival of seedlings prior to field planting. Healthy and mature seed and propagules of six mangroves namely Ceriops tagal, Sonneratia alba, Rhizophora apiculata, S. caseolaris, R. mucronata, and Xylocarpus granatum were planted in paranet shade $(0 \%, 25 \%, 50 \%, 75 \%$ and $100 \%)$ for three months. The research purpose was to study the impact of paranet shade on the growth, and morphologic characteristic in all six mangrove seedlings. Results indicated that $50 \%$ paranet shade intensity supported C. tagal, $R$. mucronata, and $S$. caseolaris seedlings for the best growth (height and diameter). By contrast, $75 \%$ intensity of the shade displayed in the optimal growth, number of leaves, and the leaves area of $R$. apiculata seedlings. We determined that the best growth of seedlings of $X$. granatum was acquired in the intensity of shade $100 \%$, contrary with $S$. alba seedling, showing $0 \%$ shade intensity as the best for growth. The tolerance to paranet of mangrove shade plants preceded the sequence of $X$. granatum (landward species) $>$ R. apiculata $>$ R. mucronata; C. tagal, and S. caseolaris $>$ S. alba (seaward species). The present works generates useful information for restoration efforts in North Sumatra and indicates the value for representative mangrove species of intensely shaded nurseries based on optimum growth and morphological characteristics.
\end{abstract}

Key words: True mangroves, light intensity, shade tolerance, rehabilitation

\section{INTRODUCTION}

Mangrove forests consist of a diverse group of separately resultant lines which are ecologically characterized because of their position within the intertidal district of the tropical and subtropical area (Tomlinson, 1986). The forest of mangroves is complex ecosystems, their performance influenced by light, salinity, tidal gradients trigger nutrient availability gradients, waterlogging, abiotic and biotic stress and patterns of propagule dispersal (Tomlinson, 1986; Smith III, 1987; Kathiresan \& Rajendran, 2002). Therefore, mangroves are an ideal system for studying the mechanism of shade tolerance that is structured by environmental gradients (Dangremond et al., 2015).

Indonesia is one of the largest mangrove forests and consists of a total of $22.6 \%$ in the world. Nevertheless, Indonesia's mangrove zones declined

\footnotetext{
* To whom correspondence should be addressed.
}

from 4.2 million (1980) to only 3.1 million (2011) (Giri et al., 2011). The forest of mangrove in North Sumatra have been found on the eastern shore by Sumatra Island, primarily at the Karang Gading and Langkat Timur Laut Wildlife Reserve (KGLTLWR), and occur under rapid threat owing to anthropogenic activity (Basyuni et al., 2015). Mangrove conservation attempts involve not only protecting coastal regions and societies from the intrusion of seawater and potential sea-level alterations but also ensuring that resources are available for future use through adaptation to evolving settings.

Several studies have proposed that mangrove plants inhabit the intertidal zone that is shade tolerance, hence explains lack of understory layer in mangrove (Smith III, 1987; Kathiresan \& Rajendran, 2002; Krauss \& Allen, 2003; LopezHoffman et al., 2007; Dangremond et al., 2015). These reports proposed that reactions to environmental gradients should be established 
proportionately to the survival and growth of seedlings. Nonetheless, a few studies are available on mangrove growth seedlings influenced by light or shade tolerance in Indonesia. Previous studies mostly have focused on salinity tolerance and elevation as an effective strategy for restoring mangrove ecosystems (Basyuni et al., 2014, 2015, 2019; Oh et al., 2017; Matatula et al., 2019). It has been reported that $50 \%$ shade delivered the best growth on Rhizophora mucronata seedlings (Ulqodri et al., 2014). This study, therefore, provides more insight for rehabilitation activities by examining the impact of the shade of paranet in growth, and morphology of six main seedlings of mangrove.

\section{MATERIALS AND METHODS}

\section{Plant materials}

The mature and healthy propagules (seeds) of the mangrove plants, Ceriops tagal C.B. Rob., Rhizophora apiculata Blume, R. mucronata Lam. (Rhizophoraceae), Sonneratia alba J. Sm., S. caseolaris (L.) Engl., (Sonneratiaceae) and Xylocarpus granatum Koen. (Meliaceae) were taken from Sembilan Island, Langkat District, North Sumatra in Indonesia. The propagules were grown for three months in bottle pots with sand in $0 \%$, $25 \%, 50 \%, 75 \%$ and $100 \%$ paranet shade with standard average temperature and sunlight in a greenhouse.

Mature propagules of C. tagal were selected being $0.8-1.2 \mathrm{~cm}$ in diameter, up to $25 \mathrm{~cm}$ or brownish-green hypocotyls or longer yellow cotyledon. Typical displays of $R$. apiculata propagules ripeness were 20-25 cm (length), 1.3-1.7 $\mathrm{cm}$ (diameter), which had green to brown hypocotyls and red cotyledon. The appropriate indicator of mature seeds of $R$. mucronata was light green with yellow cotyledon and green hypocotyls, $50-70 \mathrm{~cm}$ long and 2.0-2.3 cm diameter. Characteristics of maturity of $S$. alba was by fruit size of $40 \mathrm{~mm}$ or more and composed 150-200 seeds in the fruit, while $800-1200$ seeds in the fruit characterized $S$. caseolaris. The feature of mature fruit of $X$. garanatum was characterized by yellowish-brown, diameter $15-20 \mathrm{~cm}$, and contained 6-16 seeds. Five to thirteen of each seedling for each treatment were planted in 3 months. Subsequent to 3 months grown, six mangrove plants were extracted, cleaned and the leaves and roots were kept at $4^{\circ} \mathrm{C}$ until further investigation.

\section{Growth measurement}

Growth of C. tagal, R. mucronata, R. apiculata, $S$. caseolaris, $S$. alba, and $X$. granatum seedlings under differing paranet shades were detected by the growth rate, the diameter and stem height from the seedlings. Thus, the growth rate, diameters, and stem heights of 6 mangrove species, including 5-13 seedlings, following three months in cultivation were growth index.

\section{Morphological characteristics}

Morphological characteristics were determined by a number of leaves, leaves area of $R$. apiculata and $C$. tagal seedlings, and total biomass (dry weight) of six mangrove seedlings. A number of leaves, the leaves area, and dry weight were measured at the end of an experiment. Measurement of leaves area was done by alphanumerically scanning for measure of leave's area to make use of ImageJ processing software (Rasband, 1997-2008). The seedlings were detached for the shoot, root, and leaf contents to weigh prior drying as total biomass. The dry weights of each plant's shoots, roots and leaves were measured respectively, following $48 \mathrm{~h}$ at $75^{\circ} \mathrm{C}$ in an oven. Through these dimensions, we measured the dry weight from 6 mangrove species in individual seedlings.

\section{Statistical analysis}

The data was evaluated using ANOVA (oneway) variance analysis, followed a Dunnett's test to make comparison by treatments (paranet shade) with control. The significance threshold value was $\mathrm{P}<$ 0.05 . The statistical analysis was carried out with the statistical software program SAS ver 9.1.

\section{RESULTS AND DISCUSSION}

\section{Impact of paranet shade on seedling growth}

Seedlings growth was evaluated with plant diameter and height, and growth rate for the term. Parenet shade tolerance differs among mangrove species. The results showed that the paranet shade, $50 \%$ intensity supported the best growth (diameter and height) for C. tagal, S. caseolaris, and $R$. mucronata seedlings (Figure 1A and B). By contrast, paranet shade of $75 \%$ intensity displayed optimal growth of the leaves area and number of leaves of $R$. apiculata seedlings. Whereas, the $X$. granatum seedlings showed that $100 \%$ intensity of the shade was the best for growth. But, the result was not the same for $S$. alba seedlings, which showed the best shade intensity was $0 \%$ (Figure 1 ). In case of diameter of seedlings of $R$. apiculata, $C$. tagal, $S$. caseolaris, S. alba, and X. granatum, no difference among the treatments was observed, except in $R$. mucronata with significant increase in diameter with increase in shade of $75 \%$ paranet (Figure 1B).

This study supported the previous reports that the shade-grown seedlings showed better growth performance than under full sunlight, for example, 


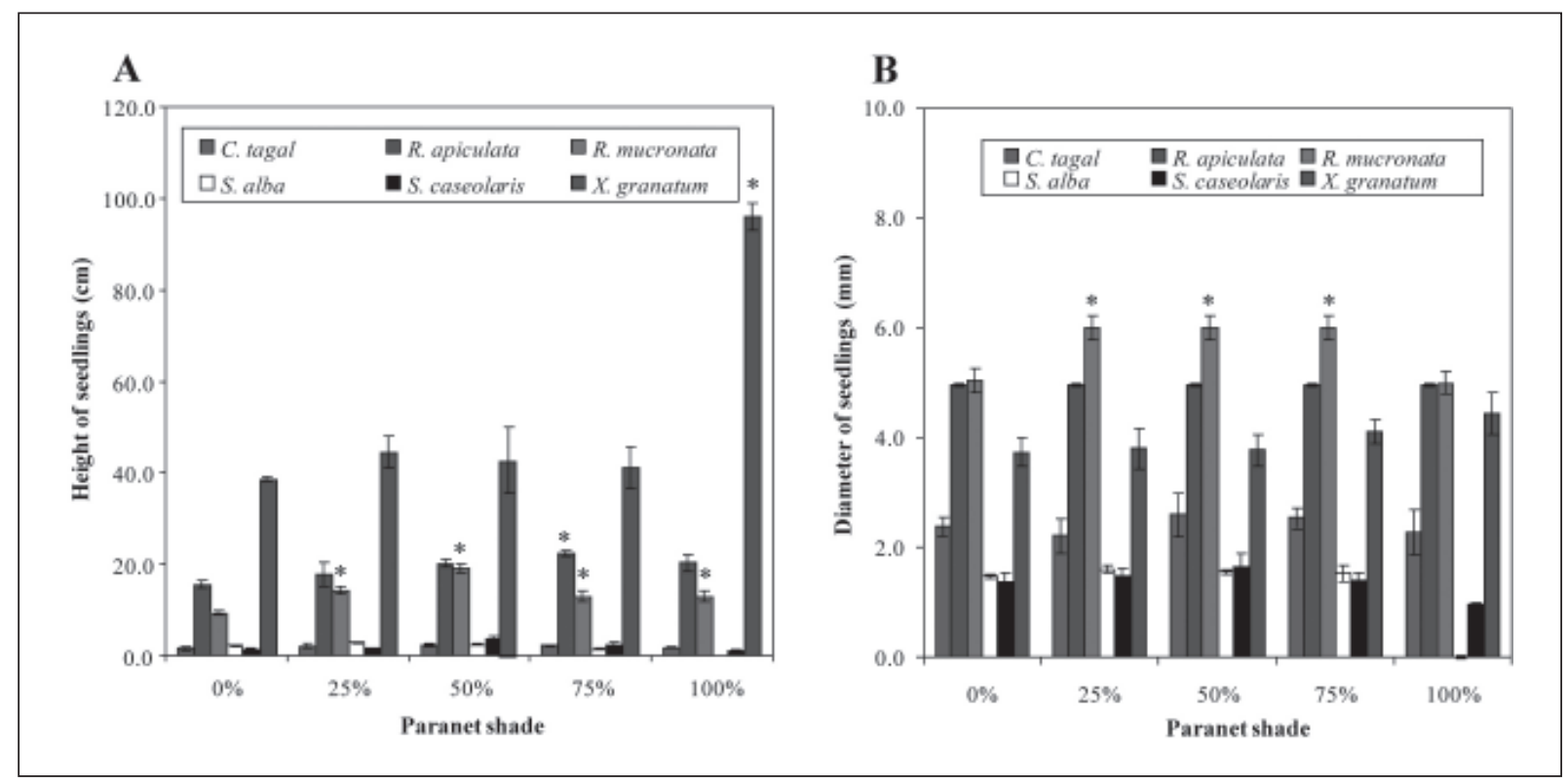

Fig. 1. Impact of paranet shade on plant height (A) and diameter (B) in six mangrove seedlings. Data presented as the means $\pm \mathrm{SE}(n=6-13)$. The asterisk shows a statistically significant alteration from $0 \%$ at $P<0.05$ by Dunnett's test.

in Bruguiera gymnorrhiza (Peng et al., 2016), B. sexangula (Krauss \& Allen, 2003), R. apiculata (Kathiresan \& Rajendran, 2002), R. mangle (Farnsworth \& Ellison, 1996), R. mucronata (Ulqodry et al., 2014). By contrast, the mangrove seedlings displayed reduced development in South Florida under a closed canopy (Koch, 1997). Furthermore, even though significant lighting impacts were traced, there was a difference in the growth and the intensity of the shade and light that almost showed a similar pattern in seedlings grown.

Our results also agreed with field conditions and other fieldwork that mangrove seedlings, which are under the completely uncovered area, often fail to expand even though other environmental factors are favourable (Kathiresan \& Rajendran, 2002). The results of the mangrove seedlings appears to confirm the environment shade (Lopez-Hoffman et al., 2007). Few determining factors that are involved for the differences in the effect of paranet shade are observed on different species are light demanding or shade-tolerant species adaptation and the intertidal zone or mangrove zonation (Osborne \& Smith, 1990; McKee, 1995). These results suggested that physiological adaptation alone can not explain the shading tolerance in mangroves frequently found across the intertidal.

\section{Effect of paranet shade on morphological characteristics}

Figure 2 shows the response of six mangroves leaves under paranet shade. The number of $R$. apiculata leaves increased in the occurrence of shade at a maximum of $75 \%$. A similar pattern was shown by $C$. tagal, R. mucronata, and S. alba, the number of leaves was significantly increased at $50 \%$ shade, this increase was attenuated when paranet shade was enhanced (Figure 2A). In contrast to this observation, $100 \%$ paranet shade decreased the number of leaves significantly in $X$. granatum, while no change of leaves number was noted in $S$. caseolaris. We observed the effect of light on leaves area on two mangroves, C. tagal and R. apiculata (Figure 2B). Different response was noted, parenet shade significantly increased leaves area in $R$. apiculata seedlings; however, paranet shade did not change the leaves area in C. tagal (Figure 2B).

Variation in growth rate is shown in Figure 3A. $R$. mucronata had a high growth rate, followed by $C$. tagal, S. alba, R. apiculata, S. caseoalaris, and $X$. granatum. Moreover, Figure $3 \mathrm{~B}$ shows the effect of the paranet shade in the dry weight of 6 mangrove species. It is noteworthy that no change of biomass was found in mangrove seedlings, except in C. tagal under $50 \%$ shade (Figure 3B). It has been reported that Rhizophora species had the highest growth rate for light tolerance, followed by Ceriops, Bruguiera, and Avicennia (Smith III, 1987). Furthermore, intense light can damage the mangrove, although mangrove forests are dispersed in subtropical and tropical areas in high light intensity. In this context, Rhizophora seedlings most easily develop and germinate under the canopy of shady bigger trees (Farnsworth \& Ellison, 1996; Kathiresan \& Rajendran, 2002; Ulqodry et al., 2014).

Growth reaction within the species was generally different, suggesting intraspecific morphological plasticity among the six mangrove 


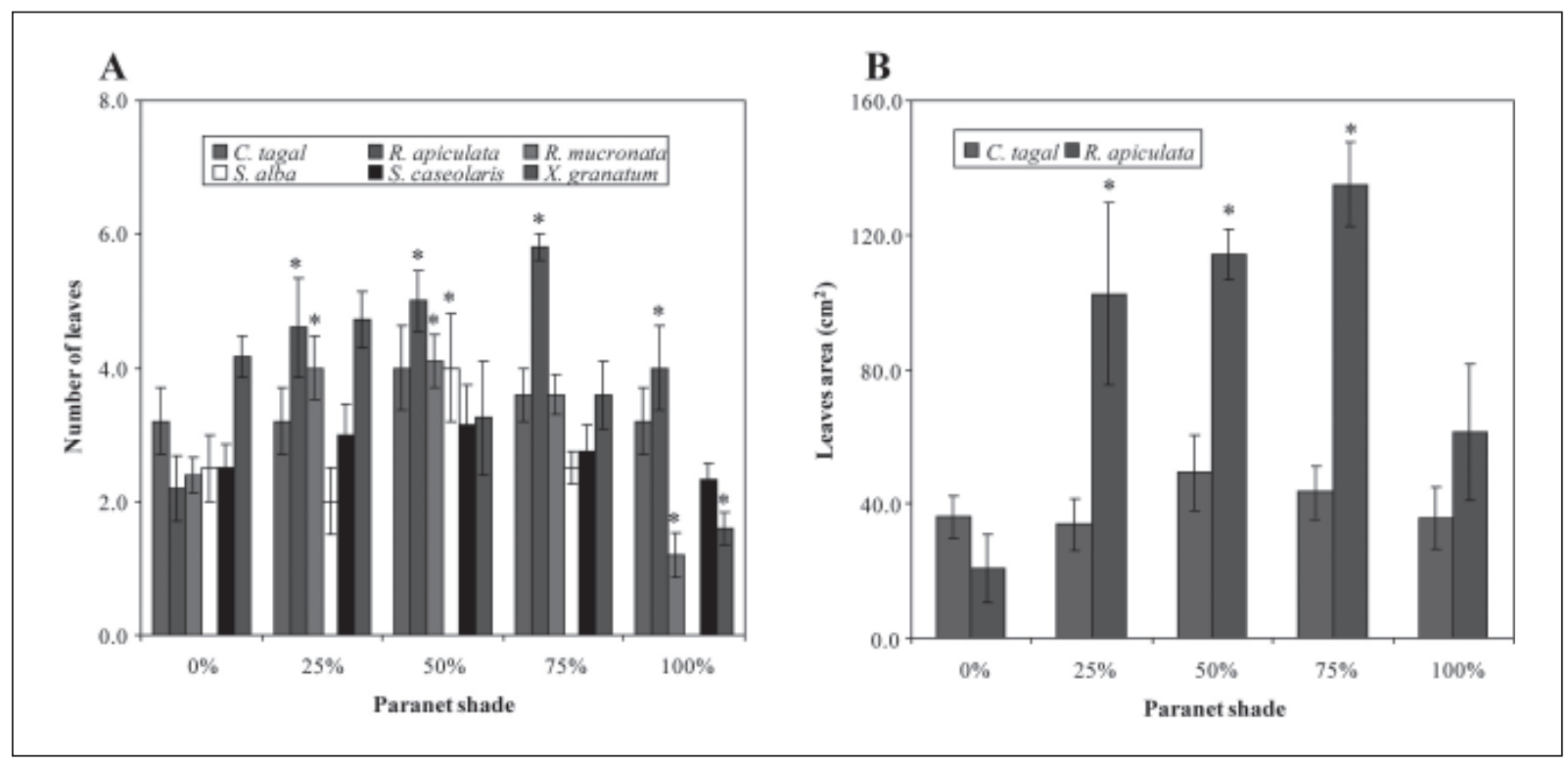

Fig. 2. Effect of paranet shade on number of leaves (A) in six mangrove species and leaves area (B) in C. tagal and $R$. apiculata seedlings. Data presented as the means \pm S.E. $(n=6-13)$. The asterisk displays a statistically significant variance from $0 \%$ at $P<0.05$ by Dunnett's test.

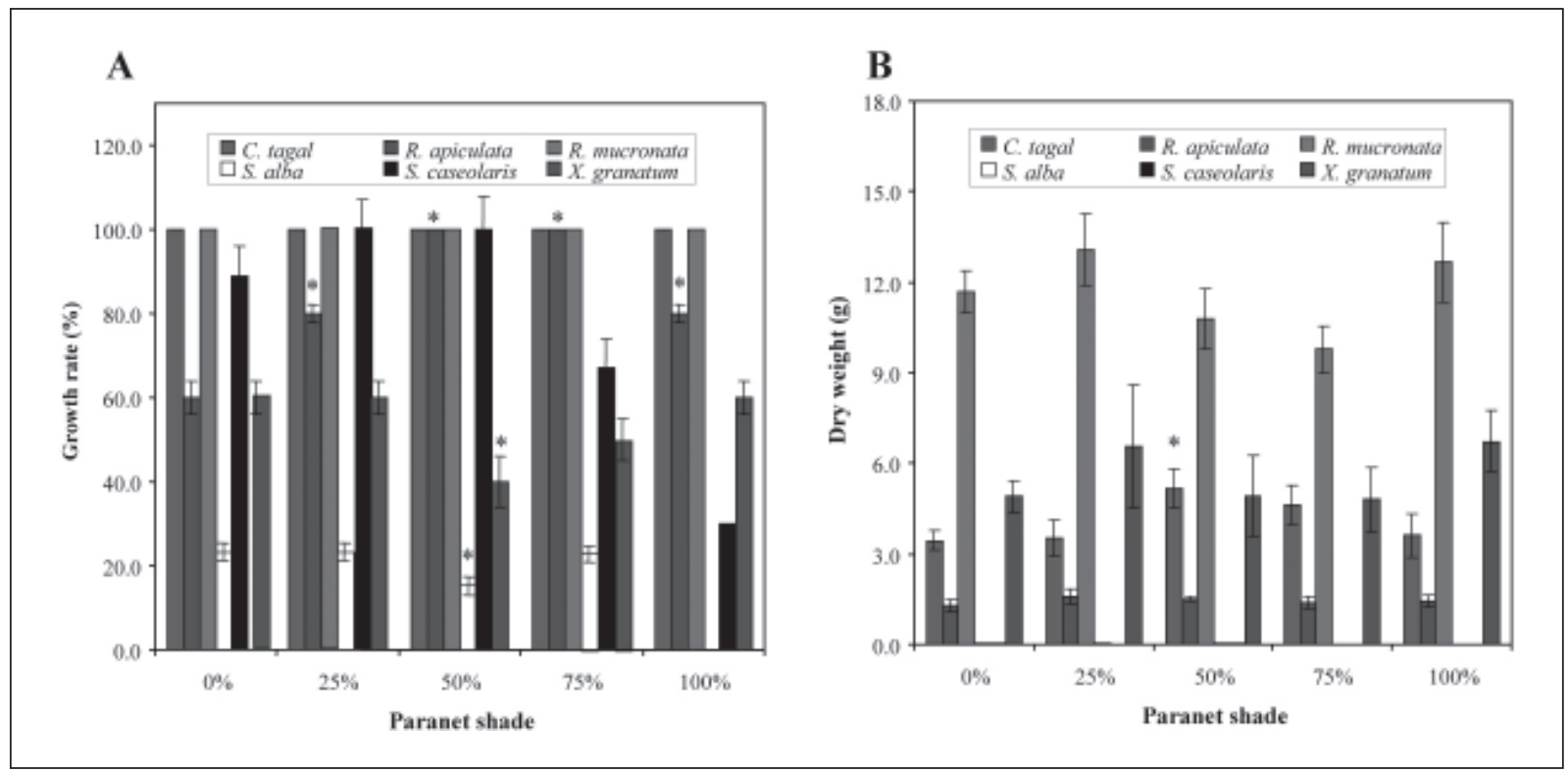

Fig. 3. Impact of paranet shade on growth rate (A) and dry weight (B) in six mangrove seedlings. Data presented as the means \pm S.E. $(n=6-13)$. The asterisk designates a statistically significant divergence from $0 \%$ at $P<0.05$ by Dunnett's test.

species. Mangrove seedlings proportionally assigned more energy to individual leaves, as propagating under paranet shade. The mangroves community frequently showed a diverse pattern of distribution of species ruled by the complexity of environmental factors (Koch, 1997; Lopez-Hoffman et al., 2007). The order of seedling survival under shade tolerance in this work, therefore, was $R$. mucronata, $C$. tagal, $X$. granatum, $R$. apiculata, $S$. $a l b a$, and $S$. caseolaris, respectively.

\section{CONCLUSIONS}

The disparate growth reaction and morphological characters among mangrove species proposed the significant analysis of individual genera or species to light tolerance mechanism. The tolerance to the shade of the mangrove species for reflecting the sequence of $X$. granatum (landward species) > R. apiculata $>$ R. mucronata, C. tagal, and $S$. caseolaris $>S$. alba (seaward species). Our study 
confirmed important data to a restoration project in North Sumatra and demonstrated significance of the nursery by the shade of intensity following the optimal growth, and morphology features to typical mangrove plants.

\section{ACKNOWLEDGEMENT}

This study was partly assisted by Competence Grant No. 117/SP2H/LT/DRPM/II/2016 from Directorate for Research and Community Service, the Ministry of Research, Technology and Higher Education, Republic of Indonesia.

\section{REFERENCES}

Basyuni, M., Putri, L.A.P., Nainggolan, B. \& Sihaloho, P.E. 2014. Growth and biomass in response to salinity and subsequent fresh water in mangrove seedlings Avicennia marina and Rhizophora stylosa. Jurnal Manajemen Hutan Tropika, 20(1): 17-25.

Basyuni, M., Putri, L.A.P. \& Murni, M.B. 2015 Implication of land use and land-cover change into carbon dioxide emissions in Karang Gading and Langkat Timur Wild Reserve, North Sumatra. Jurnal Manajemen Hutan Tropika 21(1): 25-35.

Basyuni, M., Wasilah, M., Hasibuan, P.A.Z., Sulistiyono, N., Sumardi, S., Bimantara, Y., Hayati, R., Sagami, H. \& Oku, H. 2019. Salinity and subsequent freshwater influences on the growth, biomass, and polyisoprenoids distribution of Rhizophora apiculata seedlings. Biodiversitas, 20: 288-295.

Dangremond, E.M., Feller, I.C. \& Sousa, W.P. 2015. Environmental tolerances of rare and common mangroves along light and salinity gradients. Oecologia, 179: 1187-1198.

Farnsworth, E.J. \& Ellison, A.M. 1996. Sun-shade adaptability of the Red Mangrove, Rhizophora mangle (Rhizophoraceae): Change through ontogeny at several levels biological organization. American Journal of Botany, 83: 11311143.

Giri, C., Ochieng, E., Tieszen, L.L., Zhu, Z., Singh, A., Loveland, T., Masek, J. \& Duke, N. 2011. Status and distribution of mangrove forests of the world using earth observation satellite data. Global Ecology and Biogeography, 20: 154159.

Kathiresan, K. \& Rajendran, N. 2002. Growth of a mangrove (Rhizophora apiculata) seedlings as influenced by $\mathrm{GA}_{3}$, light and salinity. Revista de Biologia Tropical, 50: 525-530.
Koch, M.S. 1997. Rhizophora mangle L. seedlings development into the sapling stage across resource and stress gradient in subtropical Florida. Biotropica, 29: 427-439.

Krauss, K.W. \& Allen, J.A. 2003. Influences of salinity and shade on seedling photosynthesis and growth of two mangrove species, Rhizophora mangle and Bruguiera sexangula, introduced to Hawaii. Aquatic Botany, 77(4): 311-324.

Lopez-Hoffman, L., Anten, N.P.R., Martinez-Ramos, M. \& Ackerly, D.D. 2007. Salinity and light interactively affect neotropical mangrove seedlings at the leaf and whole plant levels Oecologia 150: 545-556.

Matatula, J., Poedjirahajoe, E., Pudyatmoko, S. \& Sadono, R. 2019. Spatial distribution of salinity, mud thickness and slope along mangrove ecosystem of the coast of Kupang District, East Nusa Tenggara, Indonesia. Biodiversitas, 20(6): 1624-1632.

McKee, K.L. 1995. Interspecific variation in growth, biomass partitioning, and defensive characteristics of neotropical mangrove seedlings: response to light and nutrient availability. American Journal of Botany, 82(3): 299-307.

Oh, R.R.Y., Friess, D.A. \& Brown, B.M. 2017. The role of surface elevation in the rehabilitation of abandoned aquaculture ponds to mangrove forests, Sulawesi, Indonesia. Ecological Engineering, 100: 325-334.

Osborne, K. \& Smith, T.J. 1990. Differential predation on mangrove propagules in open and closed canopy forest habitats. Vegetatio, 89(1): $1-6$.

Peng, Y., Diao, J., Zheng, M., Guan, D., Zhang, R., Chen, G. \& Lee, S.Y. 2016. Early growth adaptability of four mangrove species under the canopy of an introduced mangrove plantation: implications for restoration. Forest Ecology and Management, 373: 179-188.

Rasband, W.S. 1997-2008. Image J.U.S. National Institutes of Health, Bethesda, Maryland, USA http://rsb.info.nih.gov/ij/.

Smith III, T.J. 1987. Effects of light and intertidal position on seedling survival and growth in tropical tidal forests Journal of Experimental Marine Biology and Ecology, 110: 133-146.

Tomlinson, P.B. 1986. The Botany of Mangroves. Cambridge University Press, London. 419 pp.

Ulqodry, T.Z., Matsumoto, F., Okimoto, Y., Nose, A. \& Zheng, S.H. 2014. Study on photosynthetic responses and chlorophyll fluorescence in Rhizophora mucronata seedlings under shade regimes. Acta Physiologiae Plantarum, 36(7): 1903-1917. 
